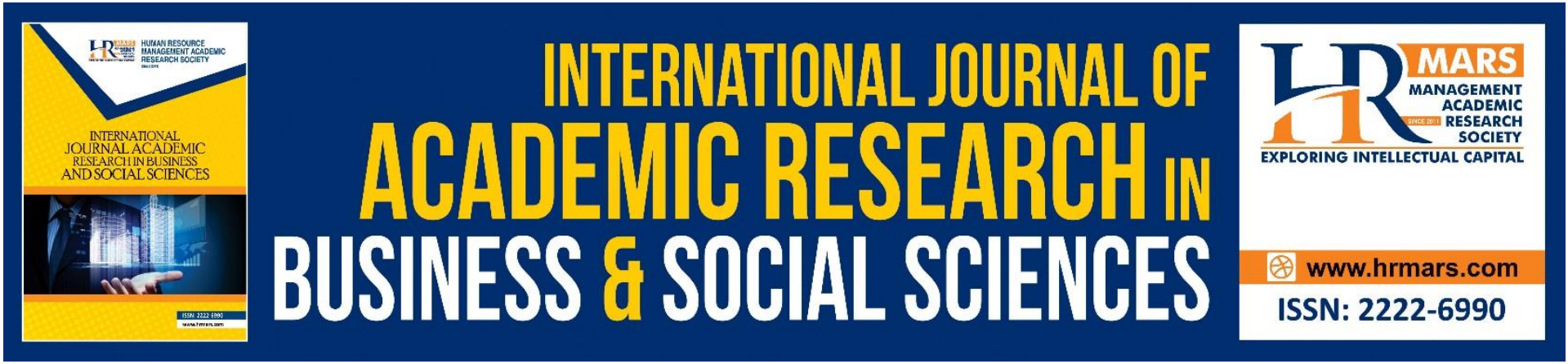

\title{
Adopting E-Commerce into S2b Company to Improve Sales Opportunities in Lumber Industry
}

\section{Sim Boon Keng, Sabrinah Adam}

To Link this Article: http://dx.doi.org/10.6007/IJARBSS/v11-i4/9548

DOI:10.6007/IJARBSS/v11-i4/9548

Received: 02 February 2021, Revised: 05 March 2021, Accepted: 23 March 2021

Published Online: 10 April 2021

In-Text Citation: (Keng \& Adam, 2021)

To Cite this Article: Keng, S. B., \& Adam, S. (2021). Adopting E-Commerce into S2b Company to Improve Sales Opportunities in Lumber Industry. International Journal of Academic Research in Business and Social Sciences, 11(4), 53-30.

Copyright: @ 2021 The Author(s)

Published by Human Resource Management Academic Research Society (www.hrmars.com)

This article is published under the Creative Commons Attribution (CC BY 4.0) license. Anyone may reproduce, distribute, translate and create derivative works of this article (for both commercial and non-commercial purposes), subject to full attribution to the original publication and authors. The full terms of this license may be seen at: http://creativecommons.org/licences/by/4.0/legalcode

Vol. 11, No. 4, 2021, Pg. 53 - 60

Full Terms \& Conditions of access and use can be found at http://hrmars.com/index.php/pages/detail/publication-ethics 


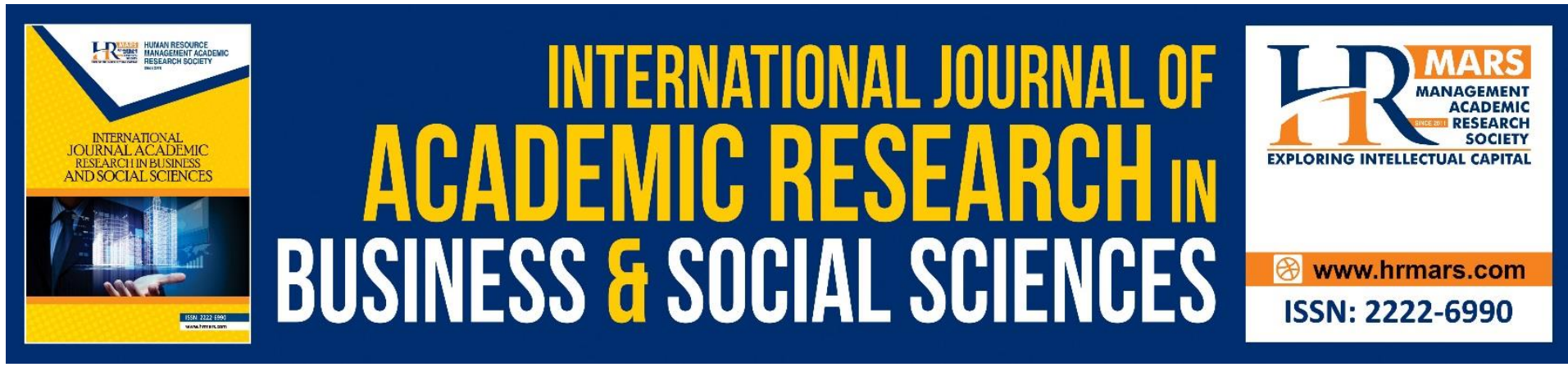

\title{
Adopting E-Commerce into S2b Company to Improve Sales Opportunities in Lumber Industry
}

\author{
Sim Boon Keng, Sabrinah Adam \\ Azman Hashim International Business School, Universiti Teknologi Malaysia (UTM), Malaysia \\ Email: keng90@graduate.utm.my, sabrinah@utm.my
}

\begin{abstract}
The purpose of this action research is to identify the workability of adopting e-commerce into S2B Company in the lumber industry to improve sales opportunities. The objective of this research is to increase sales opportunities through Alibaba e-commerce platform. The methodology adopted in this study is a combination of mixed-method by using qualitative and quantitative method. The population of this study consist of employee of S2B Company, customers and the sampling technique is a subjective sampling of 33 participants. Due to the small population, qualitative method will involve only three participants. The expected result will be an in sales opportunities. Hence laying the foundation for further improvement and a guideline for other small business in the same industry.
\end{abstract}

Keywords: Lumber Industry, E-Commerce, Sales Opportunities, Small Business, Timber

\section{Introduction}

Business innovation is an evolution of processes, services or products that affect positively towards a society, introduce in an organization (Ortiz-Villajosa \& Sotoca, 2018). The ultimate goals of business innovation is to modernize a business, creating new value and boosting growth and productivity. E-commerce, is a product of business innovation, also known as electronic commerce or internet commerce, refers to buying and selling of products or services via internet, and the transfer of money and data to execute these transactions. Thus, e-commerce is chosen in this study in order to improve the sales opportunity of S2B Company.

S2B Co., is a small company located in the town of Tawau within the state of Sabah, Malaysia. This company had been in the lumber industry for over 20 years focuses on trading woods and timber products in the local and global markets with an employment size of 50 people. Its conventional business is operating in a highly volatile environment where competition are steep with big corporation able to offers equivalent products at a cheaper price, causing the reduction of work force to almost 10 employees to maintain business competitiveness and survivability, forcing it to think of an alternative solution.

The lumber industry have been in strict government and organization scrutiny due to the concern of environmental issue. This has been identify leading to the business downfall and shared interest to rejuvenate the company business. It started off with the stagnation of 
business performance since 2013 with the Voluntary Partnership Agreements (VPA) signed between Indonesia and EU to control deforestation in Indonesia (Obidzinski, Dermawan, Andrianto, Komarudin, \& Hernawan, 2014). This has a huge business impact due to majority of timber supplies in this company are imported from Indonesia. Under the VPA, Indonesia will export only verified legal timber products. With majority of the supplies cut-off, the company are forced to look for alternative local supplies leading to sudden price hike. Following this phenomena, consumers started looking for competitors that can offer cheaper price. The recent pandemic Covid-19 had also took a toll on the company business volume. Government had issued movement control order, restricting physical interaction to the minimal. As the company is running a conventional business model, this had directly cause sales volume to drop significantly with no alternate source of income.

This study is focused on the increase in sales opportunity by adopting Alibaba as ecommerce platform. Therefore, by implementing Alibaba as e-commerce platform, sales opportunity will improve and increase the chance of survivability of this small company.

\section{Literature Review}

\section{Timber Industry Outlook in Malaysia}

Based on Malaysia Timber Industry Board, MTIB (2020) export and import statistic, Malaysia total timber export for the past decade had increase 15\% from RM 19,488 million (2009) to RM 22,503 million (2019) while import totaled RM 5,946 million (2019). Sabah had contributed RM 2,633 million or 13.5\% from the annual export in 2009 and RM 1,097 million or $4.9 \%$ in 2019 , a significant decrease of more than $50 \%$ for the past decades. The export target had been readjusted from initial RM 53 billion down 50\% to about RM 25-30 billion (Zainul, 2017). This indicate that there have indeed been a decrease in industry performance across the years which contributed to the downfall of S2B Company.

Malaysian Timber Certification Scheme (MTCS) is a voluntary scheme that provides independent assessment for forest management and chain of custody certification to ensure the sustainable management of Malaysia Permanent Reserved Forest (PRF) (Malaysia Timber Council, 2016). Started in 2001, (Lewis \& Davis, 2015) studies found that MTCS significant improvements in forest management systems of Peninsular Malaysia. This also leads to a series of sustainability policy implementation, one positive policy implemented is Sustainable Forest Management (SFM) policy, (A.S.Abdul-Rahim \& Mohd-Shahwahid, 2012) research utilize linear and nonlinear test of convergence effect indicating long term timber production can be sustainable under this policy. Throughout the negativity in this industry, government and organization have been putting afford to ensure the sustainability of industry players.

\section{The Effect of Pandemic Covid-19}

Severe acute respiratory syndrome coronavirus 2 or better known as COVID-19 were first reported by officials in Wuhan City, China, in December 2019 (WHO, 2020, p. 2). The disease was later confirmed ecologically originated from bat population causing an outbreak pandemic spread widely to rest of the world and more than 49 million people worldwide were infected with 1.24 million deaths as of Nov 2, 2020 (NIKKEI, 2020). Most people infected with the COVID-19 virus will experience respiratory problem and recover without special treatment. Older people, and those with underlying medical problems are more likely to develop serious sickness. 
COVID-19 had severely affected the timber industry due to the movement control and various restriction impose by the government and organization around the world. It had particularly hurt the timber industry in a sense that timber is big, usually the size of beams, planks and unique in every piece of it. Consumers who buy timber would most preferred to view the products personally and choose on the spot. Apart from that, the pandemic had also prevented face-to-face business transaction as timbers were usually ordered in large quantity thus the payment was significantly larger than retails, consumers would normally preferred physical transaction.

\section{Selecting an E-Commerce Platform}

E-commerce had provided a simplified methods to shopping. A user that own an electronic device such as smartphone can simply scroll through the Internet and search for any products, goods or services and procure it at the comfort of its own, regardless of situation. Based on an article by United Nations of Conference on Trade and Development, UNICTAD (2020) global online shoppers have increase $9 \%$ from 1.114 billion in 2017 to 1.452 billion in 2018 . It also stated the share of cross-border online shoppers to all online shoppers rose from $17 \%$ in 2016 to $23 \%$ in 2018. The increase years-over-years in online shoppers indicates that consumers are less-likely to go for physical shopping more often. For business owners, they may need to take into consideration the needs of a physical stores, adapting to the change in trends. One of the advantage of e-commerce is businesses no longer restricted to the local markets, customers and location, their audience are all round the world.

According to Google, well known e-commerce sites in Malaysia are Lazada.com with 31.29 million online traffic, Shopee.com with 10.88 million online traffic and Mudah.com with 12.37 million online traffic. Most of the e-commerce sites cater B2C with some C2C business. Given the nature of timber, the sales are preferably large in quantity. The company requires an online marketplace that is penetrate-able to both B2C and preferably B2B customers. Upon serious consideration, Alibaba platform is most suitable. Founded in 1999 by Jack Ma, the company went public with biggest record IPO of USD 25 billion. Alibaba has become the most valuable company in Asian with market capitalization of USD 500 billion (Iwamoto, 2019). A survey conducted by (Blazyte, 2020) estimated the number of mobile monthly active users reaching 846 million as of the first quarter of 2020 .

\section{Research Methodology}

This research focuses on improving sales opportunities of S2B Co by implementing timber product marketing via e-commerce platform Alibaba. Due to the nature of this action research must understand the current situation affecting the sales volume through conventional business and the effect of intervention solution. Therefore, in order to conduct this study, qualitative and quantitative research were used with a total simple random sampling size of 33 participants.

Qualitative research was first approach as the information required to be collected was readily available in the top management of the company, obtained via interview protocol with 3 participants. Later, the Statistical Package for the Social Sciences (SPSS) 26.0 is used to analyze the quantitative data collected via survey questionnaires of 30 timber online customer post intervention solution, and the outcomes are then interpreted based on established statistical significance figures (Pallant, 2011). Validity and reliability were prior tested via Cronbach's alpha coefficient, clarity and to obtain the duration required to 
complete the questionnaires. To perform this pre-test, the instrument was distributed to experts in this industry with a sampling size of 10 .

\section{Data Analysis}

Two types of data were collected for analysis, qualitative interview with the intended respondents and quantitative survey questionnaires with the online timber customers. The interview were conducted via voice call in plain English to collect 5 types of information, company demographic information, company situation, business innovation requirement, Alibaba intervention solution and concluding questions (Kuckartz, 2014). The questionnaire was also provided in English only and was used to collect 4 types of information, respondent profile, e-commerce adoption in timber industry, Alibaba intervention solution and concluding questions (Kuckartz, 2014). The data analysis for qualitative method will be using thematic analysis suggested by Creswell (2009) and for quantitative method will be using SPSS.

The primary data interviews are conducted with the higher management and CEO of the company. This process of interview begins with making an appointment. Validity and reliability test were conducted before data collection. Based on the selected analytical tool used, the outcome of the expected research findings can prove the research question.

Table 1 shows the approach and data analysis to every research question.

Table 1. Research Question with Approach

\begin{tabular}{llll}
\hline \multicolumn{1}{c}{ Research Question } & \multicolumn{1}{c}{ Approach } & \multicolumn{1}{c}{ Data Analysis } \\
\hline RQ1 & $\begin{array}{l}\text { What is the current sales } \\
\text { performance? }\end{array}$ & & \\
\hline RQ2 & $\begin{array}{l}\text { What business innovation can } \\
\text { help increase sales? }\end{array}$ & $\begin{array}{l}\text { Qualitative Method - } \\
\text { Interview }\end{array}$ & $\begin{array}{l}\text { Thematic analysis, } \\
\text { manual data } \\
\text { transcribe }\end{array}$ \\
\hline RQ3 & $\begin{array}{l}\text { How e-commerce platform } \\
\text { (Alibaba) does helps improve } \\
\text { sales performance? }\end{array}$ & \\
\hline
\end{tabular}

Secondary data survey questionnaires were designed based on the research objective in this action research as mentioned in below Table 2: -

TABLE 2

RESEARCH OBJECTIVE

- RO 1 (PHASE 1 - DIAGNOSIS)

- RO 2 (PHASE 2 - PLANNING)

- RO 3 (PHASE 3 - TAKING ACTION)

$\bullet$

- RO 4 (PHASE 4 - EVALUATING ACTION)

\section{Research description}

Identify the current conventional business sales volume and how it had been affected timber industry changes and pandemic Covid-19.

Develop a proposal and identify the candidate intervening solution to tackle the problem.

Validate the findings of Phase 2 by implementing the solution

Reflect and evaluate the solution. Based on the experience gained at the end of one cycle of $A R$, the study's implications, limitations and future research will be examined.

There are 30 questions that measure each single concept. To measure each construct, the questions that can be evaluated with reliability were used. The questionnaires were drafted in English and Likert-scale was used for the developed questionnaire. 


\section{Expected Finding}

From the intervention, at first the process of getting sales opportunity will be slow. With plenty of company marketing their products online, getting notice will take some time. Due to timber being a unique product, eventually sales opportunities will come. In conventional business model, this opportunity will not rise due to difficulty to locate the company, not to mention in a small town. This intervention plan is to prove intrinsically sales opportunities can be improve through e-commerce business model.

\section{Recommendation}

While progressing and conducting this research, there are some limitations and difficulties arose. This intervention only targeted timber customers in Alibaba platform, customers outside Alibaba platform will not be reached. Therefore, future researchers are suggested to diversify the product marketing strategy into several well-known e-commerce and social platform. As such, future studies could use the research framework for other opportunities.

\section{Conclusion}

From the literature review of previous study and the current situation of lumber industry and trend, e-commerce can be a factor that influence the survivability of a company. Furthermore, e-commerce had proven its potential in the retail industry and rural area as highlighted by Liu, Min, Ma \& Liu (2021). The authors research indicates significant benefits gain by farmers in the rural area promoting their products in e-commerce platform. The current research findings can help to prove that promoting products online in an effective e-commerce platform results in better survivability of a company, even more during the pandemic Covid19 crisis. To sum up, this research suggested intervention and transformation plan that can be the solution of poor sales in S2B Company in the state of Sabah. The owners of the company can use these findings as a basis in their decision making about adapting ecommerce. The expected findings of this research will be the increase in sales opportunities and survivability by adopting S2B Company into e-commerce business model.

\section{References}

Barnham, C. (2015). Quantitative and Qualitative Research: Perceptual Foundations. International Journal of Market Research, 837-854.

Blazyte, A. (2020). Alibaba Group - statistics \& facts. Statista.

Bucher, J. (2010). Using the logic model for planning and evaluation: Examples for new. Home Health Care Management \& Practice, 325-333.

Casell, \& Johnson. (2006). Action research: explaining the diversity. Human Relations, 783814.

Collis, J., \& Hussey, R. (2014). Business research: A practical guide for undergraduate and postgraduate students. Palgrave Macmillian.

Frechtling, J. (2007). Logic modeling methods in program evaluation. San Francisco: JosseyBass.

Iwamoto, K. (2019, December 26). Alibaba becomes most valuable Asian company as market cap tops $\$ 500 \mathrm{bn}$. Retrieved from Nikkei Asia: https://asia.nikkei.com/Business/Markets/Alibaba-becomes-most-valuable-Asiancompany-as-market-cap-tops-500bn 
Lewis, \& Davis. (2015). Forest certification, institutional capacity, and learning: An analysis of the impacts of the Malaysian Timber Certification Scheme. Forest Policy and Economics Volume 52, 18-26.

Liu, M., Min, S., Ma, W., Liu, T. (2021). The adoption and impact of E-commerce in rural China: Application of an endogenous switching regression model. Journal of Rural Studies, 106116.

Malaysia Timber Council. (2016). MALAYSIAN TIMBER CERTIFICATION SCHEME (MTCS). Retrieved from MALAYSIAN TIMBER CERTIFICATION SCHEME (MTCS): http://mtc.com.my/resources-MalaysianTimberCertificationScheme.php

NIKKEI. (2020). Coronavirus: Week of Nov. 1 to Nov. 7, US urges WHO to invite Taiwan to meeting. Retrieved from Coronavirus: Week of Nov. 1 to Nov. 7, US urges WHO to invite Taiwan to meeting: https://asia.nikkei.com/Spotlight/Coronavirus/Coronavirus-Freeto-read/Coronavirus-Week-of-Nov.-1-to-Nov.-7-US-urges-WHO-to-invite-Taiwan-tomeeting

Obidzinski, K., Dermawan, A., Andrianto, A., Komarudin, H., \& Hernawan, D. (2014). The timber legality verification system and the voluntary partnership agreement (VPA) in Indonesia: Challenges for the small-scale forestry sector. Forest Policy and Economics $48,24-32$.

Ortiz-Villajosa, J. M., \& Sotoca, S. (2018). Innovation and business survival: A long-term approach. Research Policy, 1418-1436.

Pallant, J. F. (2011). SPSS Survival Manual. 4th Edition.

Ponterotto, Mathew, \& Raughley. (2013). The Value of Mixed Methods Designs to Social Justice Research in Counseling and Psychology. Journal For Social Action in Counseling \& Psychology, 42-68.

Quinlan, C. (2011). Business Research Methods. South-Western Cengage.

Rogers, S. (2019). The Role Of Technology In The Evolution Of Communication. Retrieved from Forbes: https://www.forbes.com/sites/solrogers/2019/10/15/the-role-of-technologyin-the-evolution-of-communication/?sh=34dca167493b

Saunders, Lewis, \& Thornhill. (2016). Research Onion. In S. M., L. P., \& T. A., Research Methods for Business Students, 7th Edition. Pearson.

Statista. (2020). Retail e-commerce sales worldwide from 2014 to 2021. Retrieved from Statista: https://www.statista.com/statistics/379046/worldwide-retail-e-commercesales/

Tripp, D. (2005). Action research: a methodological introduction.

WHO. (2020). Coronavirus Disease 2019 (COVID-19). Retrieved from World Health Organization: https://www.who.int/docs/default-source/coronaviruse/situationreports/20200423-sitrep-94-covid-19.pdf

Yang, Z., Jiang, A., \& Jun, M. (2013). Measuring consumer perceptions of online shopping convenience. Journal of Service Management.

Zainul, E. (2017). Malaysia cuts 2020 timber exports target amid headwinds. Retrieved from The Edge Markets: https://www.theedgemarkets.com/article/malaysia-cuts-2020timber-exports-target-amid-headwinds

Pallant, J. (2007). SPSS survival manual: A step by step guide to data analysis using SPSS for windows (3rd ed.). England: McGraw Hill Open University Press Milton Keynes, UK.

Creswell, J. (2009). In Research design: Qualitative, quantitative, and mixed methods approaches (3rd ed.). Thousand Oaks, CA: Sage Publications. 
INTERNATIONAL JOURNAL OF ACADEMIC RESEARCH IN BUSINESS AND SOCIAL SCIENCES

Vol. 11, No. 4, 2021, E-ISSN: 2222-6990 @ 2021 HRMARS

Kuckartz, U. (2014). Qualitative Text Analysis. In A Guide To Methods, Practice And Using Software. Los Angeles: SAGE. 